\title{
A case of near miss maternal mortality
}

\author{
Akanksha Sood $^{1 *}$, D. V. Kurdukar ${ }^{1}$, Rekha G. Daver ${ }^{1}$, Vidya S. Nagar ${ }^{2}$ \\ ${ }^{1}$ Department of Obstetrics \& Gynecology, Grant Medical College \& J.J. Hospital, Mumbai, Maharashtra, India \\ ${ }^{2}$ Department of Internal Medicine, Grant Medical College \& J.J. Hospital, Mumbai, Maharashtra, India
}

Received: 21 July 2014

Accepted: 8 August 2014

*Correspondence:

Dr. Akanksha Sood,

E-mail: drakankshasood@gmail.com

(C) 2014 Sood A et al. This is an open-access article distributed under the terms of the Creative Commons Attribution Non-Commercial License, which permits unrestricted non-commercial use, distribution, and reproduction in any medium, provided the original work is properly cited.

\section{ABSTRACT}

Eclampsia is a common cause of maternal morbidity and at times, mortality. Usually patients show dramatic improvement soon after delivery. But rarely eclampsia, dealt by obstetricians often, can herald an underlying lifethreatening disease process requiring intensive care support and multi- disciplinary care. Such a case is being reported here.

Keywords: Eclampsia, P.I.H. (Pregnancy induced hypertension), Anti phospholipid antibody syndrome (APS), Thrombosis, Hemorrhage

\section{INTRODUCTION}

Getting a referred case from the interiors who is on the death verge is not uncommon in tertiary care set up. But a young primigravida with essentially no preceding risk factors who gets morbid is pregnancy is a definite alarming situation.

\section{CASE REPORT}

\section{History}

A 25 years old female, primigravida with 32 weeks gestation was referred to our institute on $14 / 3 / 12$ at 10 p.m. in unconscious state with a diagnosis of "Eclampsia with pulmonary edema impending D.I.C. with impending renal failure".

She had regular antenatal care at a primary health centre and her pregnancy till date was uneventful. She had no history of pregnancy induced hypertension / pedal edema / fever / jaundice / bleeding tendency / tuberculosis / rheumatic heart disease. On 14/3/12 at 1 a.m. at home, she had 2 episodes of generalized tonic clonic convulsions followed by loss of consciousness. She was managed at a nearby PHC (loading dose of magnesium sulphate) and was referred to the tertiary centre. During transfer, she had another episode of convulsion and her blood pressure fluctuated between $140 / 98 \mathrm{mmHg}$ to 160/110 $\mathrm{mmHg}$.

On admission, her general condition was poor. She was unconscious; her pulse rate was 108/min, BP - 160/100 $\mathrm{mmHg}$, respiratory rate $-24 / \mathrm{min}$, bilateral basal crepts (+). CVS examination was normal. On CNS examination, she was responding only to deep painful stimuli. Per abdomen - Fundal height corresponding to 30 weeks, F.H.S. audible and on vaginal examination, she was in early labour. High risk for both mother and fetus was explained to the relatives. Patient was admitted in critical care unit and put on ventilatory support. Her emergency investigations revealed $\mathrm{Hb} 11.2 \mathrm{gm} \%$, platelet count 125000/cu.mm, urine albumin ++ .

Liver function tests, renal function tests, coagulation profile, serum electrolytes and blood sugar all were within normal limits. Physician's opinion was sought and antihypertensive (Cap Depin) started. Augmentation of labour was done with Oxytocin drip. Within 3 hours of admission, she delivered a fresh still born female fetus of 
$1.7 \mathrm{~kg}$. Placenta had calcifications and weighed $300 \mathrm{gm}$ and there was no retro placental clot.

Post-delivery, there was no improvement in her condition. Emergency CT scan was done which revealed intraparenchymal hemorrhage in right temporal lobe measuring $4.5 \times 3.5 \mathrm{~cm}$ with sub-Dural hemorrhage and midline shift of $1.1 \mathrm{~cm}$ to left. At this point, neurosurgeon was consulted and emergency right fronto-temporoparietal craniotomy was done with evacuation of hematoma (temporal hematoma $300 \mathrm{cc}$, subdural hematoma $300 \mathrm{cc}$ ). Patient withstood the procedure well and was shifted back to the C.C.U. Two units of whole blood and 6 units of fresh frozen plasma were given postoperatively. Now patient was shifted on tab. Atenolol and started on inj. Piperacillin and Tazobactam.

Gradually she started improving, and repeat CT scan after 2 days of evacuation of hematoma (17/3/12), was suggestive of resolving hematoma. In view of need for long term ventilatory support, tracheostomy was done. But her misery did not end here and after 2 days $(19 / 3 / 12)$, she started having repeated spikes of high grade fever and developed bilateral lower limb edema. Venous Doppler study of both lower limbs was normal. $\mathrm{X}$-ray chest was suggestive of pneumonitis (? Ventilator associated). Tracheal secretion culture report showed MRSA sensitive to Vancomycin to which patient responded well and her fever settled.

After 15 days of admission (29/3/12), she was weaned off from the ventilator and complete closure of tracheostomy was done on 3/4/12. Patient could well maintain $\mathrm{O}_{2}$ saturation off the ventilatory support. But tragedy struck again! After 3 more days she developed left upper limb thrombophlebitis. Left Upper Limb Doppler was s/o left sub-clavian and internal jugular venous thrombosis. Thrombosis was thought to have been caused by central venous line and patient was started on LMWH after consulting Neurosurgeon. Patient continued to have high grade fever. Her USG abdomen was done which was suggestive of tiny lymph nodes, so CT scan was planned which revealed multiple venous thromboses in bilateral common iliac and internal iliac veins with pulmonary thrombi.

Hence the diagnosis was revised, considering arterial hemorrhage and venous thrombosis, possibility of APS was considered. ANA \& ds-DNA were negative but LA antibodies \& anti-cardiolipin antibodies were found positive.

Patient was already on anticoagulation. She showed progressive recovery as her thrombi resolved over a fortnight. 2-D ECHO was done which showed severe Pulmonary Hypertension with EF $30 \%$.

Patient was planned for discharge, but she started to develop dry cough, breathlessness and tachycardia, X-ray chest was suggestive of pulmonary edema- she had gone into left ventricular failure.

She was treated with dobutamine, NTG and diuretics, to which she responded.

After 1 month's struggle for life, now she was afebrile, normotensive and ambulatory.

\section{Diagnosis}

After 12 weeks, LA and anti-cardiolipin antibodies were repeated and found positive confirming the diagnosis of Anti-Phospholipid antibody Syndrome (APS).

\section{DISCUSSION}

APLA are found in upto 5\% healthy subjects of general population and $35 \%$ in patients with SLE. ${ }^{1,2}$ The average prevalence of APLA in normal obstetric population is $4.7 \% .^{2}$ APLA though typically presents as bad obstetric history/early severe pre-eclampsia/I.U.G.R./thrombotic episodes, ${ }^{3}$ but it may sometimes remain undetected till it becomes life- threatening. In a study by Kaleli et al., incidence of APLA antibodies was found $25 \%$ in patients with eclampsia and $6.7 \%$ in controls. ${ }^{4}$

Awareness regarding complications of P.I.H. and timely referral as in this case helped save her life. Also the lesson learnt from her case is that if a patient of eclampsia does not show improvement within 24-48 hours post-delivery one should be on toes to investigate the patient further in the line of neurological / coagulation / immunological disorder. Unusual sites of thrombosis should prompt an investigation to exclude APLA. ${ }^{5}$

During her course in the hospital, patient had multiple brushes with death but by the grace of the almighty, with good critical care monitoring and multi-disciplinary approach, she could be saved with residual morbidity yet undefined.

Funding: No funding sources

Conflict of interest: None declared

Ethical approval: Not required

\section{REFERENCES}

1. Gezer S. Anti-phospholipid syndrome. Dis Mon. 2003 Dec;49(12):696-741.

2. F. Gary Cunningham, Kenneth J. Lenovo, Steven L. Bloom, John C. Hauth, Dwight J. Rouse, Catherine Y. Spong. Anti-phospholipid antibody syndrome. In: F. Gary Cunningham, Kenneth J. Lenovo, Steven L. Bloom, John C. Hauth, Dwight J. Rouse, Catherine Y. Spong, eds. Williams Obstetrics. 23rd ed. New York: McGraw-Hill Companies; 2010: 1152-1155.

3. Denney JM, Porter TE, Branch DW. Autoimmune diseases. In: James DK, Steer PJ, Weiner CP, Gonik B, eds. High Risk Pregnancy Management Options. 
4th ed. Amsterdam: Elsevier Saunders; 2011: 776782.

4. Kaleli B, Kaleli I, Aktan E, Turan S, Akshit F. Antiphospholipid antibodies in eclamptic women. Gynecol Obstet Invest. 1998;45:81-4.
5. ACOG Practice Bulletin No. 68. Anti-phospholipid syndrome. Obstet Gynecol. 2005 Nov;106(5 Pt 1):1113-21.

DOI: $10.5455 / 2320-1770 . i j r \operatorname{cog} 20140959$

Cite this article as: Sood A, Kurdukar DV, Daver RG, Nagar VS. A case of near miss maternal mortality. Int J Reprod Contracept Obstet Gynecol 2014;3:833-5. 